\title{
THE IMPACT OF ENVIRONMENTAL DRIVERS ON NARROW-LEAVED ASH (FRAXINUS ANGUSTIFOLIA VAHL) BUDBURST DATES
}

\section{UTJECAJ KLIMATOLOŠKIH PARAMETARA NA POČETAK OTVARANJA PUPOVA POLJSKOG JASENA (Fraxinus angustifolia Vahl)}

\author{
Ivan ANDRIĆ ${ }^{1}$, Davorin KAJBA ${ }^{1}$
}

\begin{abstract}
Summary
Narrow-leaved ash (Fraxinus angustifolia Vahl) is a fast growing and light demanding forest tree species. In Croatia, the largest complexes of this species can be found along the Sava River. The main objective of research was to determine the influence of environmental drivers on budburst dates. Research was carried out in the clonal seed orchard of Nova Gradiška through four vegetation seasons (2012, 2014, 2015 and 2016). In total, 42 clones were involved in this study. The target phase of phenology monitoring was the phase with distinct budburst and partial segregation of bud scales. Three environmental drivers were selected (temperature, precipitation and insolation) with three different summing dates $\left(1^{\text {st }}\right.$ November, $1^{\text {st }}$ December and $1^{\text {st }}$ January). Statistical data processing included the following analyses: Spearman Rank Correlation, Linear Regression, Multiple Regression and Stepwise Multiple Regression. Among three tested environmental drivers in all of the analyses performed in the study, insolation proved to be the most important factor in the description of budburst dates in narrow-leaved ash.
\end{abstract}

KEY WORDS: climate change, temperature, insolation, precipitation, phenology

\section{INTRODUCTION}

\section{UVOD}

Narrow-leaved ash (Fraxinus angustifolia Vahl, Oleaceae) is a fast growing and light demanding forest tree species, which covers central-southern Europe and northwest Africa up to the Caucasus (San-Miguel-Ayanz et al. 2016). It is a hygrophilic and predominantly thermophilic tree species that favours deep, clayed and moist soils exposed to occasional seasonal flooding. The largest complexes of narrow-leaved ash in Croatia are located along the Sava River (Fukarek 1983; Anić 1999, 2001). One of the major problems in natural narrow-leaved ash stands is the absence of regular seed yield. The background of this problem is still unexplained, but it could be the result of the synergy of several biotic and abiotic factors, as well as of silvicultural treatments. The greatest threat to the stability of forest ecosystems of narrow-leaved ash is currently posed by the phytopathogen Hymenoscyphus fraxineus T. Kowalski (Kowalski 2006). Just like in common ash (Fraxinus excelsior $\mathrm{L}$.), it first causes necroses, then defoliation, and finally tree dieback (Kowalski 2006).

The two critical priorities regarding future climate is the management of water resources and the understanding of impacts of climate change on the vegetation cover (Zeppel et al. 2014), where phenology represents the best instrument for the detection and appraisal of climate changes (Ro- 
etzer et al. 2000). In climates with distinct temporal seasonalities, forest trees employ phenology to adapt to these conditions of growth. In case of abrupt climate changes in the future, forest trees will find it more difficult to adapt to newly-formed environments, unlike plant species which have much shorter life spans. In order to assess possible impacts of climate change on the growth of different forest ecosystems in Europe, it is important to understand environmental drivers which directly influence phenological manifestations (Kramer et al. 2000).

Phenological phenomena, such as leaf unfolding, autumn colouration, leaf falling and others are influenced by several different factors. These include site competition, chemical soil composition, genetic constitution and age of an individual's; however, the greatest source of activation of all these phenomena is contained in the environmental drivers to which a species/population is exposed. De Réaumur (1735) found that the greatest impact on flushing and flowering is performed by cumulative temperatures preceding the manifestation of phenological traits. Several more factors have been identified that influence the manifestation of phenological traits, such as the length of chilling period (Murray et al. 1989; Sogaard et al. 2008; Laube et al. 2014), photoperiod (Heide 1993; Körner and Basler 2010; Caffarra and Donnelly 2011; Basler and Körner 2012; Laube et al. 2014), temperatures in the preceding autumn (Heide 2003), soil nutrient availability (Jochner et al. 2013), precipitation (Peǹuelas et al. 2002; Estiarte et al. 2011; Andrić et al. 2016) and insolation regimes (Linkosalo and Lechowicz 2006).

If temperature is the main driver of phenological manifestations in a species, then damage from late spring and early autumn frost is minimal for this species (Hänninen 1990; Häkkinen et al. 1998), but if the main driver is water availability in the soil, then damage from drought, such as embolism in the xylem, will be avoided (Magnani and Borghetti 1995). Higher precipitation quantities before the vegetation season may increase the need for temperature sums (Fu et al. 2014), which confirms that precipitation can also indirectly contribute to the beginning of leaf unfolding. The impact of precipitation on the beginning of leaf unfolding is more distinct after a dry winter, when afterwards the precipitation quantity in the spring period represents the only available water source for the plants (Shen et al. 2015). The mechanism of the effect of sun insolation on the phenological changes has not yet been fully clarified (Calle et al. 2010). Although the length of day as a separate variable is sufficient to explain physiological processes of leaf unfolding (Borchert et al. 2005; Borchert and Rivera 2001), more recent research (Calle et al. 2009) has indicated that insolation should also be perceived as an important variable in phenological studies.

According to some earlier studies (Stewart and Lhryer 1994; Yuan et al. 2007), precipitation as one of the drivers of phenological manifestations has a much greater impact on the phenology of understory plants, but not necessarily in forest ecosystems of temperate regions (Dose and Menzel 2004; Morin et al. 2010; Sherry et al. 2007). These studies draw on the fact that forest trees have much deeper roots and are thus capable of satisfying their water need from deeper layers of the pedosphere (Sarmiento and Monasterio 1983).

The objectives of this research were: 1) which of the three environmental drivers has the greatest influence on the budburst dates in narrow-leaved ash; and 2) is it possible to predict the beginning of budburst through the studied variables, and if so, with what accuracy. The results of this research could contribute to a better understanding of narrow-leaved ash responses to climate conditions in which it grows.

\section{MATERIALS AND METHODS} MATERIJALI I METODE

\section{Study area and phenology monitoring - Područje istraživanja i fenološka motrenja}

Phenology monitoring was performed in the clonal seed orchard in Nova Gradiška Forest Administration (seed region of the central Sava valley) that covers an area of $3.53 \mathrm{ha}$. The clonal seed orchard $(45.252463,17.362132)$ was established in 2005 with planting distances of $4 \times 4 \mathrm{~m}$. Research comprised 168 plants ( 42 clones with 4 ramets) over four vegetation seasons (2012, 2014, 2015 and 2016). The target phase of phenological monitoring was the phase in which budburst and partial separation of bud scales was visible. All daily values of temperature (average values); precipitation and insolation were obtained from the meteorological station Gorica (DHMZ, Meteorological and Hydrological Service of Croatia) one km away from the clonal seed orchard.

\section{Statistical analysis - Statistička obrada podataka}

Three environmental drivers were included in the research: daily temperature sum (TEMP), daily precipitation sum (PREC) and daily insolation sum (INS). Three sub-variables were created for all the three variables based on the principle of different starting date of summing. The first summing date was from November $1^{\text {st }}$ (TEMP_NOV; PREC_NOV; INS NOV), the second from December $1^{\text {st }}$ (TEMP_DEC; PREC_ DEC; INS_DEC), and the third from January $1^{\text {st }}$ (TEMP_ JAN; PREC_JAN; INS_JAN), so that nine variables were obtained for the analyses. The first step was to determine the correlation between the beginning of budburst and nine different variables. The Spearman rank correlation $\left(r_{s}\right)$ was used for this purpose. Linear regression was applied to analyze all data sets separately for the entire research period (2012, 2014, 2015 and 2016). Multivariate regression was employed to test the best subset of variables for budburst date description. The three best subsets were tested using the leap function for each parameter, which were then ranked according to the $\mathrm{R}^{2}$ criterion. In the final part, models were 
Table 1. Results of linear regression analyses

Tablica 1. Rezultati linearne regresije

\begin{tabular}{|c|c|c|c|c|c|c|c|c|}
\hline \multicolumn{2}{|c|}{ Variable } & $\mathrm{R}^{2}$ & \multicolumn{2}{|c|}{ Variable } & $\mathrm{R}^{2}$ & \multicolumn{2}{|c|}{ Variable } & $\mathrm{R}^{2}$ \\
\hline \multirow{3}{*}{ Temperature } & TEMP_NOV & 0.0000055763 & & PREC_NOV & 0.01296022 & & INS_NOV & 0.5903499 \\
\hline & TEMP_DEC & 0.02232327 & Precipitation & PREC_DEC & 0.1739241 & Insolation & INS_DEC & 0.5108205 \\
\hline & TEMP_JAN & 0.06649362 & & PREC_JAN & 0.000582928 & & INS_JAN & 0.3673219 \\
\hline
\end{tabular}

developed with stepwise method and step function, on the basis of the Akaike information criterion (AIC). All statistical analyses were carried out with RStudio software (2015).

\section{RESULTS}

\section{REZULTATI}

There is no correlation between all the three variables of temperature sums (TEMP_NOV; TEMP_DEC; TEMP_ JAN) and the beginning of budburst $\left(r_{s}=-0.003 ; r_{s}=-0.056\right.$; $\left.r_{s}=-0.086\right)$. The correlation relationships with precipitation are positive (PREC_NOV; PREC_DEC; PREC_JAN) and range between temperature and insolation in terms of their values $\left(r_{s}=0.049 ; r_{s}=0.372 ; r_{s}=0.247\right)$. The correlation coefficients for insolation variables (INS_NOV; INS_DEC; INS_ JAN) are also positive and show the most significant values in all studied factors (temperature $r_{s}=0.712$, insolation $r_{s}=0.652$ and precipitation $r_{s}=0.652$ ). Figure 1 shows mutual correlation relationships of all the studied variables.
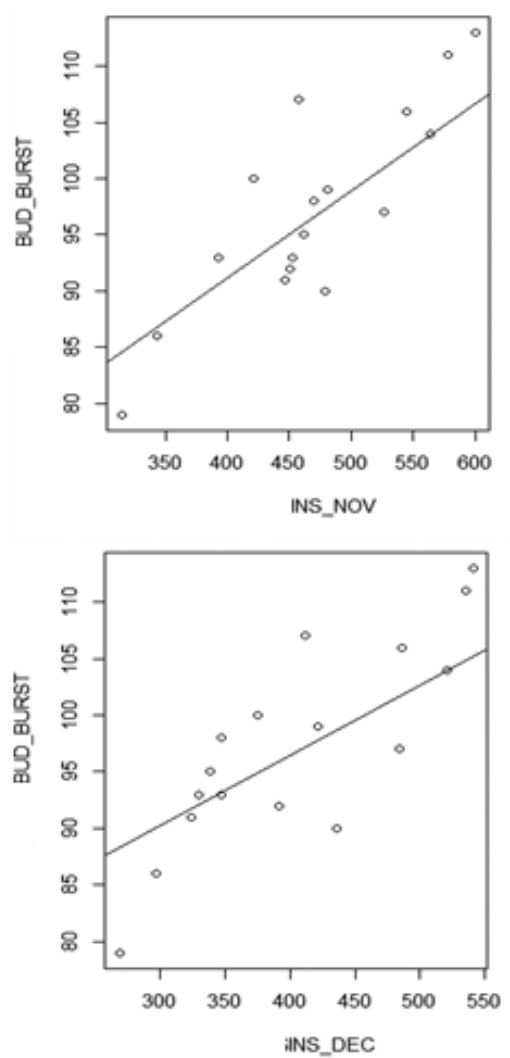

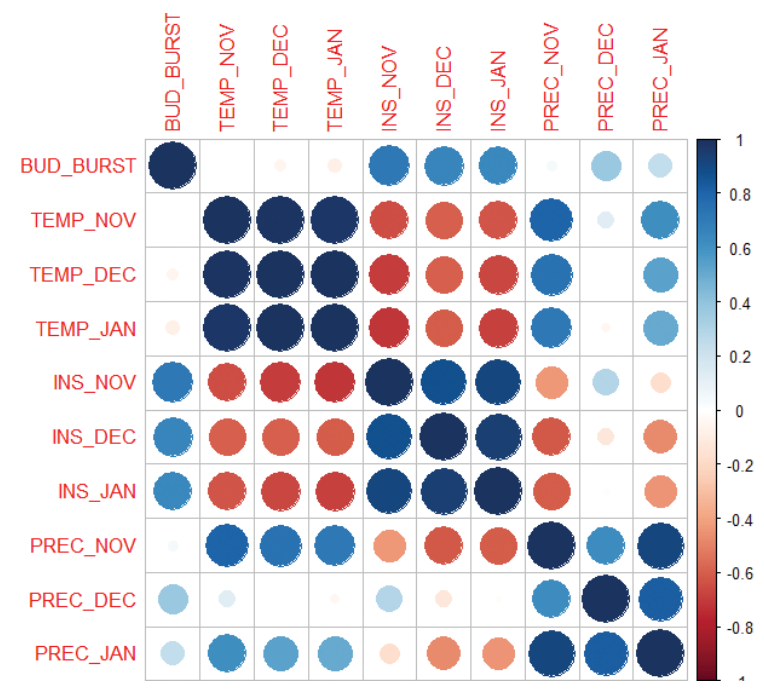

Figure 1. Correlation relationships between the investigated variables (BUD_BURST, TEMP-temperature, INS-insolation, PREC-precipitation) Slika 1. Korelacijski odnosi između istraživanih varijabli (BUD BURSTpočetak listanja, TEMP-temperatura, INS-insolacija, PREC-oborine)
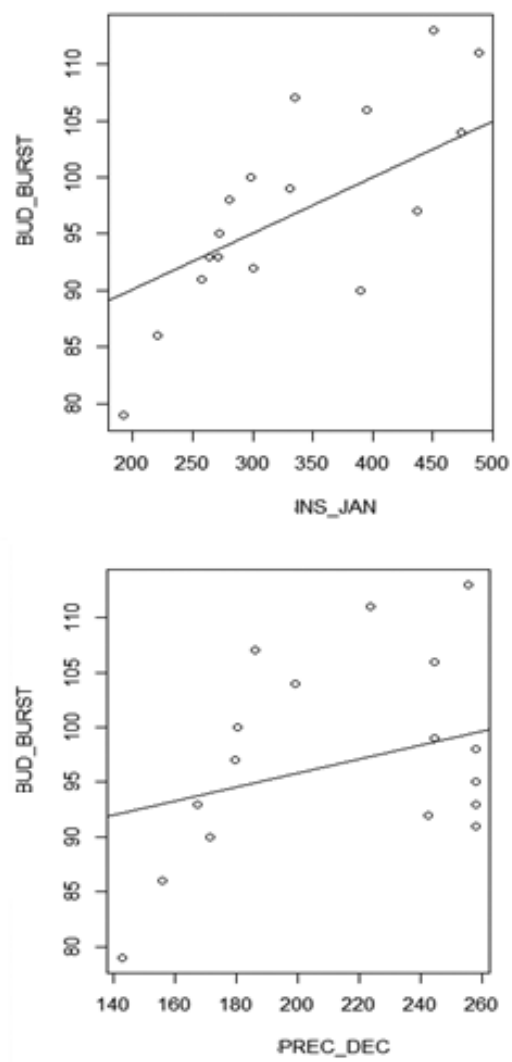

Figure 2. Linear regression relationships among some of the studied variables (INS_NOV, INS_DEC, INS_JAN and PREC_DEC) Slika 2. Grafički prikaz regresijskih odnosa nekih od istraživanih varijabli (INS_NOV, INS_DEC, INS_JAN i PREC_DEC) 


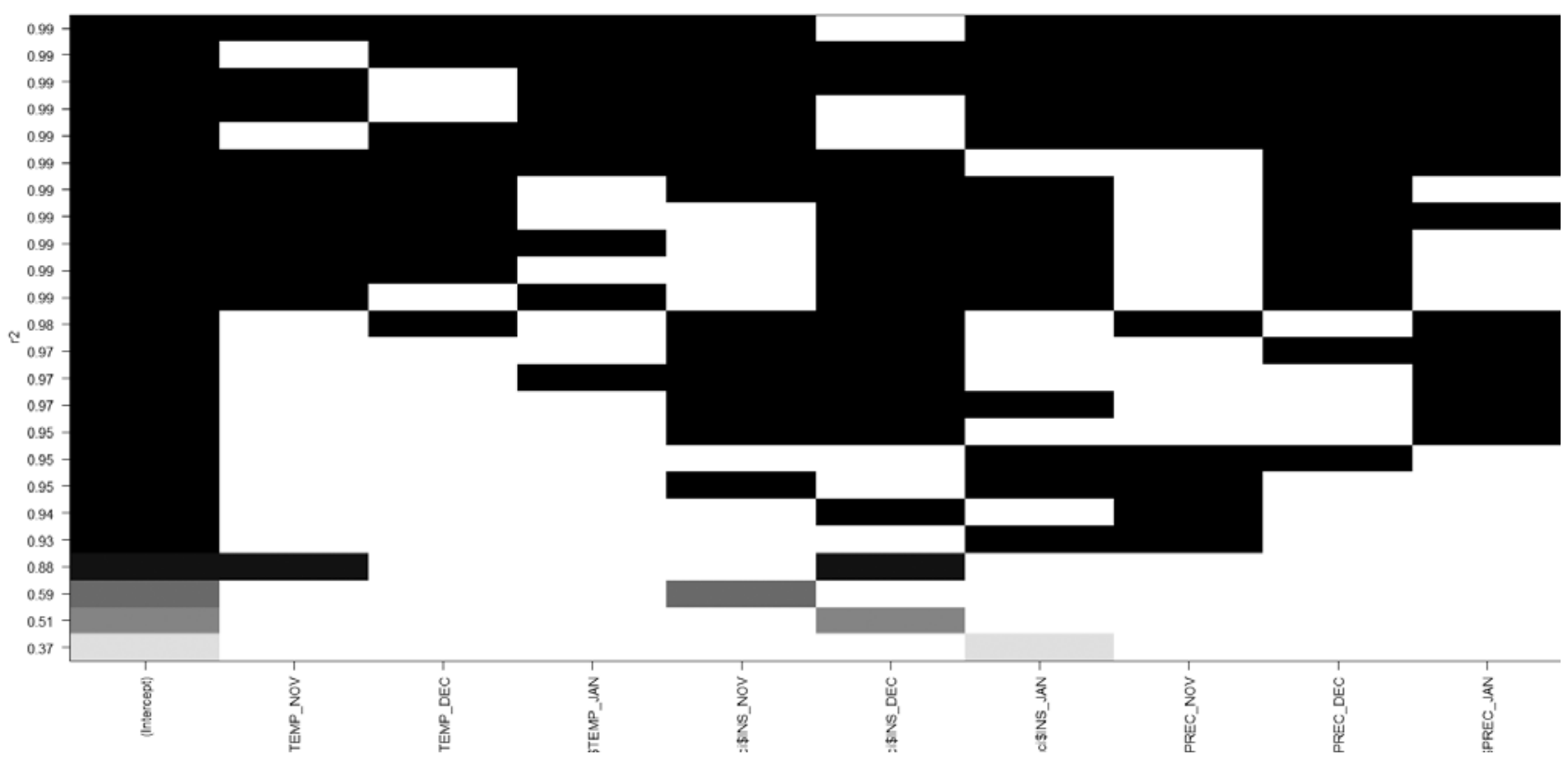

Figure 3. Results of multivariate regression analysis (stepwise). White fields - variables not included in model; Color fields - variable included in model Slika 3. Rezultat multivarijatne regresije (stepwise). Bijela polja - varijable nisu uključene u model; polja u boji - varijable uključene u model

Linear regression analyses were used to test all the variables in relation to budburst dates (Table 1). The most significant values of $\mathrm{R}^{2}$ (INS_NOV, INS_DEC, INS_JAN, PREC_DEC) are presented graphically in Figure 2.

Multivariate regression analysis was used to find the best set of variables which would describe budburst dates. Using the leap function, the three best subsets for each subset parameter were tested, and then ranked them according to the $\mathrm{R}^{2}$ criterion (Figure 3 ). As seen from the graph, five variables had to be included for the lowest $\mathrm{R}^{2}$ value of 0.99 (TEMP_NOV, TEMP_JAN, INS_DEC, INS_JAN and PREC_DEC), whereas eight variables had to be included for the highest value (all except INS_DEC).

The last step in testing the impact of environmental variables on the beginning of budburst also involved multivariate regression analysis with stepwise method and step function. The criterion used was the Akaike information criterion (AIC, lower values - more significant impacts). The results of stepwise multivariate regression analysis are shown in Table 2.
The best model for describing the beginning of budburst according to the AIC criterion is the fifth model.

\section{DISCUSSION \\ RASPRAVA}

\section{Temperature - Temperatura}

Temperature is the most widely investigated climatological parameter (environmental driver) in terms of phenological modelling. Pinto et al. (2011) used the example of Quercus ilex and Quercus suber to study the relationship between mean daily temperatures and budburst dates. Along with all the other factors, it was temperature that proved to be the most important. In contrast to the mentioned study, this work uses the example of narrow-leaved ash to sum mean daily temperature values during the four years of research and from three different starting dates. Temperature values did not have an important impact on budburst dates. This fact serves to prove that there is no uniform prediction model and there are no identical requirements that affect the beginning of leaf unfolding in forest trees.

Table 2. Results of multivariate regression (stepwise)

Tablica 2. Rezultati multivarijatne regresije (stepwise)

$\begin{array}{ccl}\text { Model } & \text { AIC } & \text { Included variables } \\ \text { 1. } & 1842.93 & \text { BUD_BURST INS_NOV } \\ \text { 2. } & 1393.71 & \text { BUD_BURST INS_NOV + TEMP_NOV } \\ 3 . & 833.67 & \text { BUD_BURST INS_NOV + TEMP_NOV + INS_DEC } \\ 4 . & 375.82 & \text { BUD_BURST INS_NOV + TEMP_NOV + INS_DEC + PREC_JAN } \\ 5 . & 173.74 & \text { BUD_BURST INS_NOV + TEMP_NOV + INS_DEC + PREC_JAN + TEMP_DEC } \\ 6 . & 327.98 & \text { BUD_BURST INS_NOV + TEMP_NOV + INS_DEC + PREC_JAN + TEMP_DEC + PREC_NOV } \\ 7 . & 811.62 & \text { BUD_BURST INS_NOV + TEMP_NOV + INS_DEC + PREC_JAN + TEMP_DEC + PREC_NOV + PREC_DEC } \\ \text { 8. } & 848.29 & \text { BUD_BURST INS_NOV + TEMP_NOV + INS_DEC + PREC_JAN + TEMP_DEC + PREC_NOV + PREC_DEC + INS_JAN } \\ 9 . & 859.33 & \text { BUD_BURST INS_NOV + TEMP_NOV + INS_DEC + PREC_JAN + TEMP_DEC + PREC_NOV + PREC_DEC + INS_JAN + TEMP_JAN }\end{array}$




\section{Precipitation - Oborine}

Seasonal changes in precipitation quantities often lead to physiological stress, changes in the phenology, and reduced increment; however, the impact predominantly depends on trends in changed precipitation quantities through the seasons of the year (Zeppel et al. 2014). Unlike temperature sums, in this investigation precipitation proved to be much more important for budburst date modelling. The importance of precipitation was tested in rain forest and mountain forest ecosystems (Huete et al 2006; Suresh and Sukumar 2011; Grogan and Schulze 2012). Using the example of narrow-leaved ash as one of the representatives of floodplain forest sites in Europe, it can be concluded that it is precisely site ecology that partially attributes importance to precipitation. In forest and grassland ecosystems, changed precipitation quantities in summer and spring periods have a much higher impact on vegetation than changes in autumn and winter periods (Zeppel et al. 2014).

\section{Insolation - Insolacija}

In some parts of tropical ecosystems, insolation represents an important factor for phenological modelling (Huete et al. 2006; Asner and Alencar 2010). Fu et al. (2015) points out that neither photoperiod nor insolation should be omitted or considered a less important factor in modelling spring phenological changes. In this investigation, in relation to temperature and precipitation, insolation showed considerable deviations in all the performed analyses. In terms of its light requirement during growth and development, narrow-leaved ash is ranked among heliophilic forest tree species, which allows us to draw a parallel between phenological manifestations and insolation.

We can assume that in heliophilic species and species of floodplain forest sites, precipitation and insolation are the principal activating factors of phenological manifestations, while in species of xerothermal sites this role is played mostly by temperature (Pinto et al. 2011).

\section{CONCLUSIONS}

\section{ZAKLJUČCI}

Between three investigated meteorological factors (temperature, precipitation, insolation), insolation summed from $1^{\text {st }}$ November (INS_NOV) to the onset of budburst $\left(r_{s}=0.712\right)$ had the highest influence on budburst in narrowleaved ash.

According to the results of linear regression analysis, insolation also digressed from temperatures and precipitation. The highest $\mathrm{R}^{2}$ was recorded in insolation sums, also from $1^{\text {st }}$ November (INS_NOV), where $\mathrm{R}^{2}$ amounted to 0.590 .

Using multivariate regression analysis ranked by the $\mathrm{R}^{2}$ criterion, the highest value is obtained if all the studied vari- ables are included, except insolation (INS_DEC) summed from $1^{\text {st }}$ December.

Multivariate regression analysis with stepwise method and step function according to the AIC criterion showed that Model 5 was the best $(\mathrm{AIC}=173.74$; BUD_BURST $\sim$ INS $\mathrm{NOV}+\mathrm{TEMP} \_\mathrm{NOV}+\mathrm{INS} \_\mathrm{DEC}+\mathrm{PREC} \_J A N+\mathrm{TEMP}$ DEC).

\section{ACKNOWLEDGMENTS ZAHVALE}

This work was supported by the Croatian Science Foundation through the research project "The role of biotic agents on the vitality of narrow-leaved ash (Fraxinus angustifolia Vahl) in Croatian floodplain forests" FRAXINPRO [IP-112013].The authors gratefully acknowledge the generous assistance of the employees of Nova Gradiška Forest Office in field measurements.

\section{REFERENCES}

\section{LITERATURA}

- Andrić, I., I. Poljak, M. Milotić, M. Idžojtić, D. Kajba, 2016: Fenološka svojstva listanja poljskog jasena (Fraxinus angustifolia Vahl) u klonskoj sjemenskoj plantaži, Šum. list, CXXX (3-4): 117-126.

- Anić, I., 2001: Uspijevanje i pomlađivanje sastojina poljskog jasena (Fraxinus angustifolia Vahl) u Posavini, Disertacija, Šumarski fakultet Zagreb.

- Anić, I., 1999: Regeneration of narrow-leaved ash stands (Fraxinus angustifolia Vahl) in central Croatia, Glas. Šum. pokuse, 34 : 1-40.

- Asner, G.P., A. Alencar, 2010: Drought impacts on the Amazon forest: the remote sensing perspective, New Phytol., 187: 569-78.

- Basler, D., C. Korner, 2012: Photoperiod sensitivity of bud burst in 14 temperate forest tree species, Agric. For. Meteorol., 165: 73-81.

- Borchert, R., S.S. Renner, Z. Calle, D. Navarrete, A. Tye, L. Gautier, R. Spichiger, P. von Hildebrand, 2005: Photoperiodic induction of synchronous flowering near Equador, Nature, 433: 627629.

- Borchert, R., G. Rivera, 2001: Photoperiodic control of seasonal development and dormancy in tropical stem-succulent trees, Tree Physiol., 21: 213-221.

- Caffarra, A., A. Donnelly, 2011: The ecological significance of phenology in four different tree species: effects of light and temperature on bud burst, Int. J. Biometeorol., 55: 711-721.

- Calle, Z., A.H. Strahler, R. Borchert, 2009: Declining insolation induces synchronous flowering of Montanoa and Simsia (Asteraceae) between Mexico and Equador, Trees, 23: 1247-1254.

- Calle, Z., B.O. Schlumpberger, L. Piedrahita, A. Leftin, S.A. Hammer, A. Tye, R. Borchert, 2010: Seasonal variation in daily insolation induces synchronous bud break and flowering in the tropics, Trees, 24: 865-877.

- DHMZ (Meteorological and Hydrological Service of Croatia), http://meteo.hr/

- Dose, V., A. Menzel, 2004: Bayesian analysis of climate change impacts in phenology, Glob. Change. Biol., 10: 259-272. 
- Estiarte, M., G. Puig, J. Peñuelas, 2011: Large delay in flowering in continental versus coastal populations of a Mediterranean shrub, Globularia alypum, Int. J. Biometeorol., 55: 855-865.

- Fu, Y.H., S. Piao, H. Zhao, S.J. Jeong, X. Wang, Y. Vitasse, P. Ciais, I.A. Janssens, 2014: Unexpected role of winter precipitation in determining heat requirement for spring vegetation green-up at northern-middle and high latitudes, Glob. Chang. Biol., 12: 3743-3755.

- Fu, Y.H., S. Piao, Y. Vitasse, H. Zhao, H.J. de Boeck, Q. Liu, H. Yang, U. Weber, H. Hanninen, I.A. Janssens, 2015: Increased heat requirement for leaf flushing in temperate woody species over 1980-2012: effects of chilling, precipitation and insolation, Glob. Change Biol., 21(7): 2687-2697.

- Fukarek, P., 1983: Poljski jasen. U: Potočić, Z. (ur.) Šumarska enciklopedija, Svezak II. Jugoslavenski leksikografski zavod „Miroslav Krleža“, Zagreb.

- Grogan, J., M. Schulze, 2012: The impact of annual rainfall patterns on growth and phenology of emergent tree species in southeastern Amazonia, Brazil, Biotropica, 44: 331-340.

- Häkkinen, R., T. Linkosalo, P. Hari, 1998: Effects of dormancy and environmental factors on timing of bud burst in Betula pendula, Tree Physiol., 18: 707-712.

- Hänninen, H., 1990: Modelling bud dormancy release in trees from cool and temperate regions, Acta For. Fenn., 231: 1-47.

- Heide, O.M., 1993: Daylength and thermal time responses of budburst during dormancy release in some northern deciduous trees, Physiol. Plant., 88: 531-540.

- Heide, O.M., 2003: High autumn temperature delays spring bud burst in boreal trees, counterbalancing the effect of climatic warming, Tree Physiol., 23: 931-936.

- Huete, A.R., K. Didan, Y.E. Shimabukuro, P. Ratana, S.R. Saleska, L.R. Hutyra, W. Yang, R.P. Nemani, R. Myneni, 2006: Amazon rainforests green-up with sunlight in dry season, Geophysical Research Letters, 33: L06405.

- Jochner, S., M. Alves-Eigenheer, A. Menzel, L.P.C. Morellato, 2013: Using phenology to assess urban heat islands in tropical and temperate regions, Int. J. Climatol., 33: 3141-3151.

- Körner, C., D. Basler, 2010: Phenology under global warming, Science, 327: 1461-1462.

- Kramer, K., I. Leinonen, D. Loustau, 2000: The importance of phenology for the evaluation of impact of climate change on growth of boreal, temperate and Mediterranean forests ecosystems: an overview, Int. J. Biometeorol., 44: 67-75.

- Kowalski, T., 2006: Chalara fraxinea sp. nov. associated with dieback of ash (Fraxinus excelsior) in Poland, For. Path., 36: 264270.

- Laube, J., T.H. Sparks, N. Estrella, J. Hofler, D.P. Ankerst, A. Menzel, 2014: Chilling outweighs photoperiod in preventing precocious spring development, Glob. Chang. Biol., 20: 170-182.

- Linkosalo, T., M.J. Lechowicz, 2006: Twilight far-red treatment advances leaf bud burst of silver birch (Betula pendula), Tree Physiol., 26: 1249-1256.

- Magnani, F., M. Borghetti, 1995: Interpretation of seasonal changes of xylem embolism and plant hydraulic resistance in Fagus sylvatica, Plant Cell Environ., 18: 689-696.
- Morin, X., J. Roy, L. Sonie, I. Chuine, 2010: Changes in leaf phenology of three uropean oak species in response to experimental climate change, New Phytol., 186: 900-910.

- Murray, M.B., M.G.R. Canell, R.I. Smith, 1989: Date of budburst of fifteen tree species in Britain following climatic warming, J. Appl. Ecol., 26: 693-700.

- Peñuelas, J., I. Filella, P. Comas, 2002: Changed plant and animal life cycles from 1952 to 2000 in the Mediterranean region, Glob. Chang. Biol., 8: 531-544.

- Pinto, C.A., M.O. Henriques, J.P. Figueiredo, J.S. David, F.G. Abreu, J.S. Pereira, I. Correia, T.S. David, 2011: Phenology and growth dynamics in Mediterranean evergreen oaks: Effects of environmental conditions and water relations, Forest Ecol. Manag., 262(2011): 500-508.

- de Reaumur, R.A.F., 1735: Comparées avec celles qui ont été faites sous la ligne, à l'isle de France, à Alger et quelques unes de nos isles de l'Amérique., Memoires de l'Académie des Sciences de Paris, France

- Roetzer, T., M. Wittenzeller, H. Haeckel, J. Nekovar, 2000: Phenology in central Europe - differences and trends of spring phenophases in urban and rural areas, Int. J. Biometeorol., 44: 6066.

- RStudio Team (2015). RStudio: Integrated Development for R. RStudio, Inc., Boston, MA URL http://www.rstudio.com/

- San-Miguel-Ayanz, J., D. de Rigo, G. Caudullo, T. Houston Durrant, A. Mauri, (Eds.), 2016: European Atlas of Forest Tree Species, Publication Office of the European Union, Luxembourg.

- Sarmiento, G., M. Monasterio, 1983: Life forms and phenology En: Bourliere, F. (Ed). Ecosystems of the World XIII, Tropical Savannas, Elsevier, Amsterdam, pp. 79-108.

- Shen, M., S. Piao, N. Cong, G. Zhang, I.A. Janssens, 2015: Precipitation impacts on vegetation spring phenology on the Tibetan Plateau, Glob. Chang. Biol., 21(10): 3647-3656.

- Sherry, R.A., X. Zhou, S. Gu, J.A. Arnone, D.S. Schimel, P.S. Verburg, L.L. Wallace, Y. Luo, 2007: Divergence of reproductive phenology under climate warming, Proceedings of the National Academy of Sciences, USA 2007; 104:198-202.

- Sogaard, G., O. Johnsen, J. Nilsen, O. Junttila, 2008: Climatic control of bud burst in young seedlings of nine provenances of Norway spruce, Tree Physiol., 28: 311-320.

- Stewart, D.W., L.M. Lhryer, 1994: Appearance time, expansion rate and expansion duration for leaves of freld-grown maize (Zea mays L.), Can. J. Plant. Sci., 74: 31-36.

- Suresh, H.S., R. Sukumar, 2011: Vegetative phenology of tropical montane forests in the Nilgiris, South India, J. Natn. Sci. Foundation Sri Lanka, 39(4): 337-347.

- Yuan, W.P., S.G. Liu, G.S. Zhou, G. Zhou, L.L. Tieszen, D. Baldocchi, C. Bernhofer, H. Gholz, A.H. Goldstein, M.L. Goulden, D.Y. Hollinger, Y. Hu, B.E. Law, P.C. Stoy, T. Vesala, S.C. Wofsy, 2007: Deriving a light use efficiency model from eddy covariance flux data for predicting daily gross primary production across biomes, Agric. For. Meteorol., 143: 189-207.

- Zeppel, M.J.B., J.V. Wilks, J.D. Lewis, 2014: Impacts of extreme precipitation and seasonal changes in precipitation on plants, Biogeosciences, 11: 3083-3093. 


\section{Sažetak}

Poljski jasen (Fraxinus angustifolia Vahl) je brzorastuća heliofilna vrsta, koja u Hrvatskoj tvori veće ili manje prirodne šumske komplekse duž toka rijeke Save. Jedna je od ekonomski najvažnijih vrsta šumskoga drveća, no uzmemo li u obzir značaj poljskog jasena s ekološkog gledišta, tada mu je vrijednost nemjerljivo viša. Glavni problemi u prirodnim sastojinama poljskog jasena su smanjena vitalnost i odumiranje stabala te izostanak redovnog plodonošenja, čiji se uzroci ogledaju u sinergiji više biotičkih i abiotičkih čimbenika, kao i šumskouzgojnih zahvata. Kritični prioriteti u pogledu budućnosti klime su upravljanje vodnim resursima i razumijevanje utjecaja klimatskih promjena na biljni pokrov u kojem fenologija predstavlja najbolji instrument za detekciju i procjenu klimatskih promjena. U podnebljima s izraženim vremenskim sezonalnostima šumsko drveće se na te uvjete rasta prilagođava fenologijom, te je u svrhu procjene mogućih utjecaja klimatskih promjena na uspijevanje različitih šumskih ekosustava važno razumijeti klimatske parametre koji izravno utječu na fenološka ispoljavanja. Fenološka istraživanja su provedena u klonskoj sjemenskoj plantaži na području UŠP Nova Gradiška (sjemenska regija srednja Posavina). Istraživanja su obuhvatila 168 biljaka (42 klona sa po četiri ramete po klonu) kroz četiri vegetacijske sezone. Ciljana faza fenoloških motrenja bila je faza u kojoj je vidljivo bubrenje te djelomično razdvajanje ljuski pupa. U svrhu fenološkog modeliranja izabrana su tri klimatološka parametra (temperatura, oborine i insolacija) s tri različita početna datuma zbrajanja (1. studeni; 1. prosinac i 1. siječanj). Sve dnevne vrijednosti temperatura, oborina i insolacije preuzete su od DHMZ (Državni hidrometeorološki zavod) s meteorološke postaje Gorice udaljene jedan km od klonske sjemenske plantaže. Prvi korak bio je utvrditi korelacijski odnos između početka listanja i devet različitih varijabli, za što je korištena Spearman-ova korelacija $\left(r_{s}\right)$. Linearnom regresijom analizirani su svi setovi podataka zasebno za cijeli period istraživanja (2012., 2014., 2015., 2016.). Multivarijatnom regresijom ispitan je najbolji podskup varijabli za opisivanje početka listanja. Prvotno su pomoću funkcije leap ispitana po tri najbolja podskupa za svaku veličinu, koji su kasnije rangirani po $\mathrm{R}^{2}$ kriteriju. U završnom dijelu izrađeni su modeli kroz stepwise metodu i funkciju step, a na osnovi Akaike informacijskog kriterija (AIC). Za sve tri varijable temperaturnih suma (TEMP_NOV; TEMP_DEC; TEMP_JAN) u odnosu na početak listanja nije utvrđena korelacija $\left(r_{s}=-0,003 ; r_{s}=-0,056 ; r_{s}=-0,086\right)$. Korelacijski odnosi s oborinama su pozitivni (PREC_ NOV; PREC_DEC; PREC_JAN) te su po svojim vrijednostima između temperature i insolacije $\left(\mathrm{r}_{\mathrm{s}}=0,049\right.$; $\left.r_{s}=0,372 ; r_{s}=0,247\right)$. Koeficijenti korelacije za varijable insolacije (INS_NOV; INS_DEC; INS_JAN) su također pozitivni i u odnosu na ostala dva parametra (temperatura i oborine) pokazuju najznačajnije vrijednosti $\left(r_{s}=0,712 ; r_{s}=0,652 ; r_{s}=0,643\right)$, kako je prikazano na slici 1 . Linearnim regresijskim analizama $\mathrm{R}^{2}$ dobivene su sljedeće vrijednosti za varijable temperature: TEMP_NOV, $\mathrm{R}^{2}=0,0000055763$; TEMP_DEC, $\mathrm{R}^{2}=0,02232327$; TEMP_JAN, $\mathrm{R}^{2}=0,06649362$, za oborine: PREC_NOV, $\mathrm{R}^{2}=0,01296022$; PREC_DEC, $\mathrm{R}^{2}=0,1739241$, PREC_ JAN, $\mathrm{R}^{2}=0,000582928$, a za insolaciju: INS_NOV, $\mathrm{R}^{2}=0,5903499$; INS_DEC, $\mathrm{R}^{2}=0,5108205$, INS_JAN,

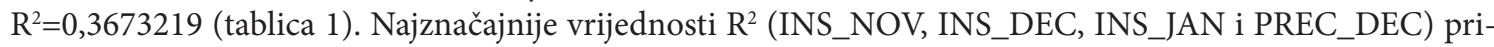
kazane su i grafički na slici 2. Multivarijantnom regresijskom analizom, a na osnovi funkcije leap ispitana su po tri najbolja podskupa za svaku veličinu podskupa te su zatim rangirani po $\mathrm{R}^{2}$ kriteriju (slika 3). Iz grafikona se zaključuje da je za najnižu vrijednost $\mathrm{R}^{2}$ od 0,99 potrebno uključiti pet varijabli (TEMP_NOV, TEMP_JAN, INS_DEC, INS_JAN i PREC_DEC), a za najvišu vrijednost osam varijabli (sve osim INS_DEC). Zadnji korak testiranja utjecaja okolišnih varijabli na početak listanja bila je također multivarijatna regresijska analiza sa stepwise metodom i step funkcijom. Korišten je Akaike informacijski kriterij (AIC, manje vrijednosti značajniji utjecaj). Rezultati stepwise multivarijatne regresijske analize prikazani su u tablici 2. Najbolji model za opisivanje početka listanja po AIC kriteriju je peti model. Od sva tri ispitana klimatološka parametra (temperatura, oborine i insolacija) i to kroz sve provedene analize u radu, insolacija se pokazala kao čimbenik koji najznačajnije opisuje početak listanja kod poljskog jasena.

KLJUČNE RIJEČl: klimatske promjene, temperatura, insolacija, oborine, fenologija 